\title{
Vermicomposting an Economical Enterprise for Nutrient and Waste Management for Rural Agriculture
}

\author{
Bharti Baghel $^{1 *}$, Rahul Sahu ${ }^{2}$ and Dushyant Pandey ${ }^{2}$ \\ ${ }^{1}$ Krishi Vigyan Kendra, Rajnandgaon (C.G.), India \\ ${ }^{2}$ Krishi Vigyan Kendra, Bastar (C.G.), India \\ *Corresponding author
}

\section{A B S T R A C T}

Environmental degradation is the major conflicts in present day, due to excessive use of chemical fertilizers and pesticides, which creates deterioration of soil resources. The common practice of waste management is obtained by vermi-composting by using earthworms as bio-fertilizers. The Krishi Vigyan Kendra, Bastar set up vermi-composting unit as a model unit for demonstration and conducted training programme in Bastar district's village like Madhota, Badechakwa, Bodanpal and Nadisagar, as they utilizes agricultural waste materials for vermi-compost as well as the bund side weeds. By using this vermi-composting technique the farmers of Badechakwa not only providing organic fertilizer also selling the earthworms ₹500/kg and earning ₹3500/tank in three months by vermi-compost. The scheme benefitted 38 farmers in Kharif season under 15 ha area, 60 $\& 30$ acre in Rabi season, which benefits 90 farmers of Bastar region. Vermi-compost used in Green gram, Chick pea and Field pea increased germination percentage of 92, 90 and 93 respectively and increased yield of 9,14 and $12 \mathrm{q} / \mathrm{ha}$ respectively. The vermi-compost applied in the Marie-Gold flower increased the number of flowers per plant i.e. average $30-32 /$ plant and increased the flowers diameter of about $8.5 \mathrm{~cm}$ maximum and gave yield 07t/ha with application of $1 / 2$ ton vermi-compost and recommended dose of fertilizers applied by the farmers of Badechakwa. So, vermi-composting is the safe dispose of biodegradable organic waste and provide additional income for landless farmers in rural agriculture.

\section{Introduction}

In the present day, environmental degradation is a major threat confronting the world and excessive use of chemical fertilizers and pesticides contributes largely to the deterioration of the environment through depletion of soil resources. It leads to loss of soil fertility due to imbalance use of chemical fertilizer and pesticides. Management of solid waste becomes one of the biggest problems we are facing today. The rapid increase in the volume of the waste is one of the aspects of the environmental crisis, accompanying recent global development. Most common practices of waste processing are uncontrolled dumping which causes mainly water and soil pollution. In natures laboratory, there are many organism (macro and micro) that have ability to convert organic waste into valuable resources 
containing plant nutrients and organic matter which are critical for maintaining soil productivity. Under this macro-organismlike earthworms are important biological organisms helping nature to maintain nutrient flows from one system to another and minimize environmental degradation.

Vermicomposting uses earthworms to achieve the same goal. The chemical secretion in the earthworm's digestive tract helps breakdown soil and organic matter, so the casting contains more nutrients that are immediately available to plants. Vermicompost is like conventional compost and can be applied in the same way to gardens, lawns and potted plants. A large volume of organic matter generated from agriculture activities, industrial establishments, animal shelters and household activities and dumped to putrefy without proper utilization. So that a simple bio composting process like vermicomposting as a bio-fertilizer provide a "Win Win" solution to tackle the problem of safe disposal of waste as well as the most needed plant nutrients for sustainable productivity (wani,2002).

\section{Materials and Methods}

Krishi Vigyan Kendra, Bastar set up a vermicomposting unit in a common place under roof with 3 cemented tanks of about $9 \times 3 \times 3$ feet size as a model unit for demonstration. To start making vermicompost, the shredded organic wastes are spared in layer and exposed to sunlight for 5-10 days to remove pathogenic micro-organisms and noxious gases. This pre-composting process takes 5-10 days for their completion.

The process was conducted in three different sets of vermicomposting unit.The important parameters i.e. moisture and temperature were controlled by means of spraying water over the bed, there by temperature maintain not to exceeding $35^{\circ} \mathrm{C}$ by adorning wet gunny bags over bed and moisture were maintained between 50-60\%. Having start with a population of earthworms in each of the tank. This pre-compost was finally covered with gunny bags to protect earthworms from birds, direct sunlight and air. The appearance of black granular powder on top of vermi beds indicates harvest stage of compost. Watering was stopped for at least 5 days at this stage and vermicompost was collected from the top without disturbing the lower layer.

\section{Results and Discussion}

So, for the primary objective of this work was to help farmers from rural areas to demonstrate and set up micro enterprises based on vermiculture technology and to improve crop productivity by increasing soil fertility through ecological methods of farming. The training programmes were conducted by KVK, Bastar for rural areas such as village Madhota, Badechakwa, Nadisagar and Bodanpal for different Self-Help Groups (SHGs) covered technical staff of multiplying earthworms, managing and collection of organic wastes, application of vermicompost in various crops. At the same time different types of noxious weeds like parthenium, button weed and broom weed etc. found in the field bunds were utilized which inhibited crop growth and caused environmental pollution.

Hence, the farmers utilize this crop as raw material for vermicomposting, which are a safe weed disposal mechanism and an opportunity to convert into valuable compost. Vermicompost is important organic input for healthy soils and plants. The most significant benefit is that the nutrients in vermicompost are very easily absorbed by the roots of plant. Having begun with a population of $1 / 2-1 / 2 \mathrm{~kg}$ earthworms of single species harvest around 2-3 ton vermicompost from 1.5-2 month. KVK, Bastar aware the farmers about vermicomposting technique, their benefits and 
helps to produce on his farm land. KVK establish the number of vermi pits on individual farms and community farm land. Farmers of village Badechakwa not only providing the vermicompost and selling the earthworms at $₹ 500 / \mathrm{kg}$. They produce approximately $300 \mathrm{~kg}$ vermicompost and $2 \mathrm{~kg}$ worms per $(9 \times 3 \times 3$ feet size pit $)$ tank in 3 months of periods. Thus total $(15000+2000=17000) \quad ₹ 3500 /$ tank in three months earn easily. Whereas, it also produces vermin wash which is an important source of micro nutrients. It has high quality of $\mathrm{N}, \mathrm{P}, \mathrm{K}$, $\mathrm{Mg}$ and $\mathrm{Zn}$. Fresh vermi wash they use as plant growth regulator. It contains auxin, Gibberellic acid, Cytokinin. It also helps to prevent various infection.

The scheme was introduced to inhance crop productivity in vegetable and flower crops in the field and enables the farmers to get more per hectare yield and economy with using low cost technology. KVK, Bastar has conducted front line demonstration with full package of practices included with use of vermicompost for promotion of pulses production in the district during Kharif 2015-16.Total 15 haarea of 38 farmers were benefited in Kharif season. Similarly, during Rabi 2015-16 Chick pea and Field pea crop on an area of 60 and 30 acres respectively covering total numbers of 90 farmers were benefitted from Bastar district under Tribal Sub Plan (TSP) entitled "Increasing Pulses Production for Food, Nutritional Security and Rural Livelihood of Tribal Community through Demonstration and Training" funded by Indian Institute of Pulses Research (IIPR), Kanpur through ICARATARI, Zone-VII, Jabalpur (M.P.).

Vermicompost plays an important role in improving germination percentage of field crops, which is presented in table -2 shows that with the application of 0.5 ton of vermicompost in Green gram, Chick pea and Field pea.It increases germination 92, 90 and
93 per cent as compare to control i.e.83, 82 and 79per cent respectively. Similarly, the application of vermicompost gave higher germination (93\%) of Moong bean (Vigna radiata) compared to the control (83\%). Further, the growth and yield of Moong bean was also significantly higher with vermicompost application. Likewise, in another pot experiment, the fresh and dry matter yields of cow pea (Vigna unguiculata) were higher when soil was amended with vermicompost than with bio digested slurry (Karmegan et al., 1999, Karmegan and Daniel 2000). The efficiency of vermicompost was evaluated in a field study by Desai et al., (1999). They stated that the application of vermicompost along with fertilizer $\mathrm{N}$ gave higher dry matter (16.2 g/plant) and grain yield (3.6t/ha) of wheat (Triticum aestivum) and higher dry matter yield $(0.66 \mathrm{~g} / \mathrm{plant})$ of the following coriander (Coriandrum sativum) crop in sequential cropping system. Similarly, a positive response was obtained with the application of vermicompost to the other field crops such as sorghum (Sorghum bicolor) (Patil and Sheelavantar 2000) and sunflower (Helianthus annus) (Devi and Agrawal 1998, Devi et al., 1998).

The yield of Field pea (Pisum sativum), Chick pea (Cicer aerietinum) and Green gram (Vigna radiata) was also higher with the application of vermicompost 0.5 t/ha along with recommended dose of $\mathrm{N}, \mathrm{P}$ and $\mathrm{K}$ than with these fertilizers alone which is recorded as $12 \mathrm{q} / \mathrm{ha}, 14 \mathrm{q} / \mathrm{ha}$ and $9 \mathrm{q} / \mathrm{ha}$ respectively than the local check, which is presented in table -2 . The yield of pea was also higher with the application of vermicompost (10 t/ha) along with recommended $\mathrm{N}, \mathrm{P}$ and $\mathrm{K}$ than with these fertilizers alone (Reddy et al. 1998). The vermicompost were also tested in vegetables like cabbage and tomato at $5 \mathrm{t} / \mathrm{ha}$ significantly increased the yield of cabbage and tomato i.e. 10.2t/ha and 5.0t/ha in farmers field as compare to local check i.e.6.5t/ha and 2.6t/ ha. 
Table.1 Produce from vermi unit and earning

\begin{tabular}{|l|c|c|c|c|}
\hline \multicolumn{1}{|c|}{ Items } & Produce $(\mathrm{kg})$ & Sale Rate $(₹ / \mathrm{kg})$ & \multicolumn{2}{|c|}{ Amount Earned (₹) } \\
\cline { 1 - 4 } & & & $\mathbf{3}$ Months & $\mathbf{1}$ Year \\
\hline Vermicompost & 300 & 05 & 3500 & 14000 \\
\hline Worms & 02 & 1000 & & 14500 \\
\hline Vermiwash & 1 liter & $500 /$ liter & 500 & \\
\hline
\end{tabular}

Table.2 Increase of germination and yield in pulse crop by using vermicompost in Kharif and Rabi 2015-16

\begin{tabular}{|c|c|c|c|c|c|c|c|c|c|}
\hline \multirow{2}{*}{$\begin{array}{l}\text { S. } \\
\text { No. }\end{array}$} & \multirow[t]{2}{*}{ Crop } & \multirow[t]{2}{*}{ Variety } & \multirow{2}{*}{$\begin{array}{c}\text { Area } \\
\text { (ha) }\end{array}$} & \multirow{2}{*}{$\begin{array}{l}\text { No. of } \\
\text { Farmers }\end{array}$} & \multirow{2}{*}{$\begin{array}{c}\text { Fertilizer Applied with } \\
\text { Vermicompost(N:P:K:S/ha) }\end{array}$} & \multicolumn{4}{|c|}{ Increase } \\
\hline & & & & & & $\begin{array}{c}\text { Germination } \\
(\%)\end{array}$ & Control & $\begin{array}{l}\text { Yield } \\
\text { (q/ha) }\end{array}$ & Control \\
\hline \multicolumn{10}{|c|}{ Kharif 2015-16 } \\
\hline 1. & $\begin{array}{l}\text { Green } \\
\text { gram }\end{array}$ & $\begin{array}{l}\text { SML- } \\
668\end{array}$ & 38 & 38 & $\begin{array}{c}20: 40: 20: 20 \\
+0.5 \text { ton vermicompost }\end{array}$ & 92 & 83 & 9 & 7.5 \\
\hline \multicolumn{10}{|c|}{ Rabi 2015-16 } \\
\hline 2. & $\begin{array}{c}\text { Chick } \\
\text { pea }\end{array}$ & JG-11 & 60 & 60 & $\begin{array}{c}10: 50: 0: 20+0.5 \text { ton } \\
\text { vermicompost }\end{array}$ & 90 & 82 & 14 & 12 \\
\hline 3. & $\begin{array}{c}\text { Field } \\
\text { pea }\end{array}$ & Shubhra & 30 & 30 & $\begin{array}{c}20: 8: 30 \\
+0.5 \text { ton vermicompost }\end{array}$ & 93 & 79 & 12 & 10.8 \\
\hline
\end{tabular}

Similar findings were already published by ICRISAT, in which application of vermicompost at $5 \mathrm{t} /$ ha significantly increased yield of tomato (Lycopersicon esculentum) $(5.8 \mathrm{t} / \mathrm{ha})$ in farmers field in Aadrsha Watershed, Kothapally, Andhra Pradesh compared to control (3.5 t/ha). Similarly, green house studies at Ohio State University at Columbus, Ohio, UAS have indicated that vermicompost enhances transplant growth rate of vegetables. Amendment of vermicompost with a transplant grown without vermicompost had the highest amount of red marketable tomato fruit at harvest. Vadiraj et al., (1998) reported that application of vermicompost produced herbage yields of coriander cultivars that were comparable to those obtained with chemical fertilizers.

The vermi compost applied in the Marie-gold flower increased the number of flowers per plant i.e. average 30-32/plant and also increased flower diameter of about $8.5 \mathrm{~cm}$ maximum and yield $7 \mathrm{t} /$ ha with application of $0.5 \mathrm{t} / \mathrm{ha}$ vermicompost and recommended dose of other fertilizers, applied by the farmers of Badechakwa. Similarly, Nethra et al. 1999, reported that the fresh weight of flowers such as Chrysanthemum chinensis increased with the application of different levels of vermicompost. Also, the number of flowers per plant (26), flower diameter $(6 \mathrm{~cm})$ and yield $(0.5 \mathrm{t} / \mathrm{ha})$ were maximum with the application of $10 \mathrm{t} / \mathrm{ha}$ of vermicompost along with $50 \%$ of recommended dose of NPK fertilizer. However, the vase life of flowers (11 days) was high with the combined application of vermicompost at $15 \mathrm{t} / \mathrm{ha}$ and $50 \%$ of recommended dose of NPK fertilizer.

The production of degradable organic waste and its safe disposal becomes the current global problem. The utilization of vermicompost results in several benefits to 
farmers like less reliance on purchased input on nutrients leading to over cost of production and lesser use of pesticides. The landless people provide additional resources of income generation and boost rural economy. It is a less wasteland function so that savings in purchased inputs and make more economical.

\section{References}

Desai, V. R., Sabale R.N. and Roundel, P.V. 1999. Integrated nitrogen management in Wheat coriander cropping system. Journal of Maharashtra Agricultural Universities 24(3):273-275.

Devi, D. and Agrawal, S.K. 1998. Performance of sunflower hybrids as influenced by organic manure and fertilizer. Journal of Oilseeds Research 15(2):272-279.

Devi, D., Agrawal, S.K. and Dayal, D. 1998. Response of sunflower [Helianthus annus (L.)] to organic manures and fertilizers. Indian Journal of Agronomy 43(3):469-473.

Karmegan, N., Alagermalai, K. and Daniel, T. 1999. Effect of vermicompost on the growth and yield of green gram (Phaseolus aureus rob.) Tropical Agriculture 76(2): 143-146.

Karmegan,N. and Daniel,T. 2000. Effect of bio-digested slurry and vermicompost on the growth and yield of cowpea [Vigna unguiculata (L.)] Environment and Ecology 18(2): 367-370.
Nehra, N.N., Jayaprasad, K.V. and Kale, R.D. 1999. China aster [Callistephus chinensis (L.)] cultivation using vermicompost as organic amendment. Crop Research Hissar 17(2):209-215.

Patil, S.L. and Sheelavantar, M.N. 2000. Effect of moisture conservation practices, organic sources and nitrogen levels on yield, water use and root development of rabi sorghum [Sorghum bicolor (L.)] in the vertisols of semiarid tropics. Annals of Agricultural Research 21(21):32-36.

Punde, B. D. and Ganoker, R.A. 2012. International Journal of Engineering Research and Applications (IJERA) vol. 2, Issue-3, May-June 2012, pp.23422347.

Reddy,R., Reddy, M. A. N., Reddy,Y. T. N., Reddy, N. S., Anjanappa, N. and Reddy, R. 1998. Effect of organic and inorganic sources of NPK on growth and yield of pea [Pisum sativum (L.)]. Legume Research 21(1):57-60.

Vadiraj, B. A., Siddagangaiah, D. and Potty, S. N. 1998. Response of coriander [Coriandrum sativum (L.)] cultivars to graded levels ofvermicompost. Journal of Spices and Aromatic Crops. 7(2):141-143.

Wani, S. P. 2002. Improving the livelihoods: New partnerships for win-win solutions for natural resource management. Paper submitted in the $2^{\text {nd }}$ International Agronomy Congress held at New Delhi, India during 26-30 November 2002.

\section{How to cite this article:}

Bharti Baghel, Rahul Sahu and Dushyant Pandey. 2018. Vermicomposting an Economical Enterprise for Nutrient and Waste Management for Rural Agriculture. Int.J.Curr.Microbiol.App.Sci. 7(02): 3754-3758. doi: https://doi.org/10.20546/ijcmas.2018.702.444 